\title{
TERAPI ULTRASOUND DENGAN LATIHAN HOLD RELAX DAN PASSIVE STRETCHING SAMA EFEKTIFNYA DALAM MENINGKATKAN FLEKSIBILITAS OTOT HAMSTRING PADA PASIEN OSTEOARTHRITIS GENU DI RSUP SANGLAH DENPASAR BALI
}

\author{
Eka Oktafianti ${ }^{1}$, Luh Putu Ratna Sundari ${ }^{2}$, Muhammad Ali Imron ${ }^{3}$, Ketut Tirtayasa ${ }^{4}$, \\ I Putu Adhiartha Griadhi ${ }^{5}$, Luh Made. Indah Sri Handari Adiputra ${ }^{6}$ \\ ${ }^{1}$ Universitas Udayana Program Studi Magister Fisiologi Keolahragaan, Denpasar \\ 2,4,5,6 Universitas Udayana Fakultas Kedokteran, Denpasar \\ ${ }^{3}$ Universitas 'Aisyiyah Fakultas Fisioterapi, D.I.Yogyakarta
}

E-mail: fiany871023@gmail.com

\begin{abstract}
ABSTRAK
Latar Belakang : Osteoarthritis lutut merupakan penyakit degeneratif yang bersifat progresif, dimana menyebabkan perubahan morfologis khususnya pada tulang rawan. Penderita osteoarthritis cenderung bermasalah dengan fleksibilitas otot hamstring dikarenakan lama osteoarthritis yang diderita sehingga mengakibatkan pemendekan otot hamstring. Pemendekan otot hamstring merupakan kondisi otot yang terjadinya penurunan elastisitas dan fleksibilitas otot atau pemendekan otot, dikarenakan pada saat otot bekerja secara terus-menerus, respon otot lebih cepat untuk membuat otot yang berlawanan terjadinya ketegangan dan pemendekan, serta akan menyebabkan otot yang bekerja lebih sedikit menjadi lemah. Tujuan : untuk membuktikan dalam peningkatan fleksibilitas otot hamstring pada pasien osteoarthritis lutut. Metode : two groups pre and post test design, populasi yang diambil adalah penderita osteoarthritis lutut yang mengalami gangguan pada fleksibilitas otot hamstring di RSUP Sanglah Denpasar Bali. Sampel dari penelitian ini telah dikelompokkan menggunakan tehnik purposive sampling. Total sampel 18 orang dibagi 2 kelompok yaitu 9 orang dalam setiap kelompok. Pada Kelompok I diberikan Terapi ultrasound dengan latihan hold relax dan Kelompok II diberikan terapi ultrasound dengan latihan passive stretching selama 6 minggu dengan 3 kali terapi perminggu. Untuk pengukuran tingkat fleksibilitas otot hamstring dengan menggunakan Chair Sit And Reach Test. Hasil : Berdasarkan nilai Chair Sit And Reach Test sebelum intervensi untuk Kelompok I dengan rerata $26,56 \pm 1,50 \mathrm{~cm}$ menurun menjadi $22,89 \pm 1,69 \mathrm{~cm}$

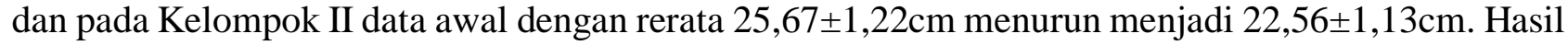
dari analisis kemaknaan uji $T$ - Independent membuktikan bahwa nilai $p=0,631$ dimana nilai $p>0.05$. Bahwa di antara kedua kelompok setelah diberi perlakuan tidak berbeda bermakna pada peningkatan fleksibilitas otot hamstring di RSUP Sanglah Denpasar Bali. Kesimpulan : Bahwa terapi ultrasonic dengan latihan hold relax dan passive stretching tidak berbeda bermakna pada peningkatan fleksibilitas otot Hamstring di RSUP Sanglah Denpasar Bali.

Kata Kunci: Terapi Ultrasonic, Hold Relax, Passive Stretching. Fleksibilitas otot hamstring, Osteoarthritis Genu.
\end{abstract}




\title{
ULTRASOUD THERAPY WITH HOLD RELAX TRAINING AND PASSIVE STRETCHING IS EQUALLY EFFECTIVE IN INCREASING MUSCLE FLEXIBILITY OF HAMSTRING IN THE PATIENT'S OSTEOARTHRITIS GENU IN RSUP SANGLAH DENPASAR BALI
}

\begin{abstract}
Background: Osteoarthritis of the knee is a progressive degenerative disease, which causes morphological changes especially in cartilage. Osteoarthritis sufferers tend to have problems with muscles flexibility of hamstring due to long duration osteoarthritis suffered, resulting in shortening of the hamstring muscles. Muscle shortening that forms muscle that has decreased elasticity and muscle displacement, depends on when the muscles are working continuously, faster muscle respons to make the muscles being debated, and shortening, and will help more muscles become weaker. Objective : To prove the increased muscles flexibility of hamstring in osteoarthritis of the knee. Methods : Two groups pre and pro test design, the population taken was knee osteoarthritis sufferers who happened muscles flexibility of hamstring at Sanglah Hospital Denpasar Bali. Samples from this study were grouped using purposive sampling techniques. Total sample of 18 people divided into 2 groups, 9 people in each group. Group I was given ultrasound Therapy with hold relax exercises and Group II was given ultrasound therapy with passive stretching exercises for 6 weeks with 3 times weekly therapy. To measure the level muscles flexibility of hamstring to use Chair Sit And Reach Test. Results : Based on Chair Sit And Reach Test value before intervention in Group I with a mean of $26.56 \pm 1.50 \mathrm{~cm}$ decreased to $22.89 \pm 1.69 \mathrm{~cm}$ and in Group II the initial data with a mean of 25.67 $\pm 1.22 \mathrm{~cm}$ decreased to $22,56 \pm 1.13 \mathrm{~cm}$. The results of the analysis of the significance of the $\mathrm{T}$ Independent test prove that the value of $p=0.631$ where the value of $p>0.05$. That between the two groups after being treated was not significantly different in increasing muscles flexibility of hamstring at Sanglah Hospital, Denpasar, Bali. Conclusion: Ultrasonic therapy with hold relax and passive stretching exercises did not differ significantly in increasing muscles flexibility of hamstring at Sanglah Hospital Denpasar Bali.
\end{abstract}

Keywords : Ultrasonic Therapy, Hold Relax, Passive Stretching. Hamstring muscle flexibility, Knee Osteoarthritis.

\section{PENDAHULUAN}

Osteoarthritis genu adalah suatu penyakit yang di sebabkan oleh faktor degeneratif, sering ditemui terhadap kondisi muskuloskeletal \& sering terjadi dalam keterbatasaan fungsi dan gerak. Osteoarthritis genu merupakan gangguan sendi lutut yang sering dilihat pada lanjut usia ${ }^{\mathbf{1}}$.

Kondisi pasien osteoarthritis cenderung mempunyai masalah dengan kelenturan otot hamstring dikarenakan lamanya osteoarthritis yang dialami ataupun pada pola jalan pasien itu sehingga mengakibatkan pemendekan otot hamstring. Hubungan di antara osteoarthritis dan gangguan kelenturan tersebut juga dibuktikan dengan penelitian yang membandingkan tingkat kelenturan hamstring pada sampel osteoarthritis dan sampel yang sehat. Ternyata sampel yang mengalami osteoarthritis genu, banyak yang mengalami gangguan kelenturan otot hamstring ${ }^{2}$.

Fleksibilitas (kelenturan) otot merupakan kemampuan otot untuk memperpanjang, memungkinkan satu sendi bergerak melewati berbagai gerakan yang mengarah pada efisiensi dan efektivitas gerakan yang membantu mencegah atau meminimalkan cidera, dan nyeri otot. Banyak faktor yang dapat mempengaruhi kelenturan individu termasuk usia, jenis kelamin, dan aktivitas ${ }^{3}$. Pada lanjut usia secara fisiologis sudah terjadi penurunan kelenturan karena pada lanjut usia terjadi perubahan struktur otot dimulai 
dari penurunan ukuran dan jumlah serabut otot, peningkatan jaringan lemak dan jaringan penghubung, fibril berubah tidak teratur ${ }^{4}$.

Otot hamstring merupakan kontributor penting untuk mengontrol gerakan dan terlibat dalam berbagai aktivitas mulai berlari dan melompat kedepan untuk membungkuk saat duduk atau berdiri dan tindakan kontrol postural. Kelenturan otot hamstring yang bagus dibuktikan dengan kemampuan otot hamstring untuk berkontraksi secara ekstrentrik dan konsentrik secara maximal. Otot hamstring yang terjadinya pemendekan dapat mempengaruhi terjadinya penurunan keseimbangan atau kekuatan otot terjadi kontraksi menjadi tidak sinergi sehingga dalam kasus tertentu akan menimbulkan disfungsi pada lumbal ${ }^{5}$.

Pemendekkan (Tightness) otot hamstring dapat terjadi pada saat otot bekerja secara intensif, respon otot lebih cepat untuk terjadi pemendekan. Pemendekkan (Tightness) membuat otot yang berlawanan hamstring bekerja lebih keras. Keadaan ini akan membuat otot yang bekerja lebih sedikit menjadi lemah. Seandainya otot yang memendek tetap didiamkan maka pola jalan seseorang akan ikut berubah ${ }^{6}$.

Salah satu penyebab terjadinya pemendekan otot hamstring adalah aktivitas yang tidak terkontrol yang menyebabkan gangguan pada postur, akibatnya mengalami penurunan fleksibilitas pada otot hamstring.

Ultrasound adalah jenis thermotherapy yang bisa menurunkan nyeri akut maupun kronis, dengan menggunakan arus listrik yang di alirkan melewati transduser yang bisa mengembang dan kontraksi serta menghasilkan gelombang suara yang dapat di transmisikan oleh kulit serta ke dalam tubuh. Ultrasound diterapkan pada gelombang 0,8 - $3 \mathrm{MHz}(800-3,000 \mathrm{KHz})^{7}$.

Micromassage ialah efek lain secara biologis dengan menghasilkan reflex fisiologis dari pengaruh panas dan mekanic. Efek biologis dari ultrasound antara lainnya dapat meningkatkan relaksasi otot dan sirkulasi darah. Terutama, dalam terapi ini bisa di gunakan untuk kondisi kontraktur otot yang disebabkan oleh spasme otot di karenakan mempunyai efek meningkatkan kelenturan jaringan.

Sedangkan terapi latihan merupakan salah satu modalitas pada penanganan kondisi Osteoarthritis lutut. Seperti, hold relax ialah salah satu modalitas dalam bentuk terapi latihan yang menggunakan metode Proprioceptive Neuromuscular Facilitation (PNF) dan terdapat unsur kontraksi isometrik pada kelompok otot antagonis di dalamnya serta diberikan tahanan maksimal.

Pemberian terapi latihan berupa hold relax merupakan salah satu tehnik di mana kontraksi isometric bisa memicu otot antagonis yang terjadinya pemendekkan serta di ikuti dengan kurangnya maupun hilangnya spasme dari beberapa otot yang telah di terapi. Tujuannya ialah untuk memfasilitasi relaksasi otot agar mencapai lingkup gerak sendi dengan menggunakan tehnik kontraksi isometric ${ }^{8}$.

Passive Stretching adalah suatu tehnik penguluran di mana seseorang pada kondisi relaks dan tidak melakukan gerakan lainnya, serta pada stretch dibantu dengan orang lain. Misalnya, penguluran pada kaki dengan bantuan terapis, untuk menciptakan posisi peregangan yang lebih besar. Latihan ini dapat meningkatkan aliran darah ke otot, lalu akan membawa nutrisi ke otot dan membuang limbah metabolism dari otot sehingga dapat juga mempercepat penyembuhan cidera otot atau sendi .

Berdasarkan teori yang telah saya jelaskan diatas maka saya sebagai peneliti tertarik untuk meneliti dan membuktikan "Terapi Ultrasonic dengan Latihan Hold Relax Dan Passive Stretching Sama Efektifnya Dalam Meningkatkan Fleksibilitas Otot Hamstring Pada Pasien Osteoarthritis Genu”.

\section{METODE PENELITIAN}

Menggunakan metode penelitian eksperimental dengan susunan penelitian berupa randomized pre and pro test group control design, penelitian ini telah di laksanakan di RSUP Sanglah Denpasar, Bali. Pelaksanakan terapi selama 6 minggu serta melakukan dua tahap penelitian dimulai dari pengumpulan teori yang dilakukan pada bulan Agustus hingga 
Desember 2018 dan penelitian yang telah Uji Normalitas Uji Homogenitas

Kelompok (Shapiro Wilk Test) (Levene's Test)

Perlakuan

\begin{tabular}{cccc} 
& $p>0,05$ & & $p>0,05$ \\
\hline Pre & Post & Pre & Post
\end{tabular}

$\begin{array}{lllll}\text { Kelompok I } & 0,915 & 0,241 & 0,599 & 0,367\end{array}$

Kelompok II $\quad 0,266 \quad 0,106$

dilakukan dimulai dari bulan April - Juni 2019. Populasi penelitian ini ialah seluruh pasien yang telah di diagnosis penyakit Osteoarthritis Genu di RSUP Sanglah Denpasar, Bali. Tehnik pemilihan sampel pada penelitian ini ialah purposive sampling sehingga sampel untuk setiap kelompok ialah 9 orang dengan total sampel 18 orang. Kelompok I terdiri dari 9 orang diberi ultrasound dengan latihan hold relax disebut Kelompok Kontrol. Kelompok II terdiri dari 9 orang diberi terapi Ultrasound (US) dengan latihan passive stretching disebut dengan Kelompok Perlakuan.

\section{HASIL PENELITIAN}

\section{Karakteristik Pasien Penelitian}

Tabel 1

Hasil penelitian di RSUP Sanglah Denpasar

\begin{tabular}{llll}
\hline \multirow{2}{*}{\begin{tabular}{c} 
Karakteristik \\
\multicolumn{1}{c}{ Sampel }
\end{tabular}} & Rentangan & \multicolumn{1}{c}{$\begin{array}{c}\text { Kelompok I } \\
(\mathrm{n}=18)\end{array}$} & $\begin{array}{c}\text { Kelompok II } \\
(\mathrm{n}=18)\end{array}$ \\
\cline { 3 - 4 } & & Mean \pm SD & Mean \pm SD \\
\hline Umur (th) & $60-80$ & $66,22 \pm 4,02$ & $66,33 \pm 6,36$ \\
Berat Badan $(\mathrm{kg})$ & $50-70$ & $52,00 \pm 1,73$ & $54,89 \pm 3,62$ \\
Tinggi Badan $(\mathrm{cm})$ & $150-170$ & $159,44 \pm 3,12$ & $160,22 \pm 4,46$ \\
\hline
\end{tabular}

2. Hasil Pengukuran Flexibilitas Otot Pada Chair Sit And Reach Test

Tabel 2

Hasil Penelitian di RSUP Sanglah Denpasar

Bali

\begin{tabular}{lccc}
\hline Karakteristik & Pre & Post & Selisih \\
\cline { 2 - 4 } Sampel & $\begin{array}{c}\text { Mean } \pm \text { SD } \\
(\mathrm{cm})\end{array}$ & $\begin{array}{c}\text { Mean } \pm \text { SD } \\
(\mathrm{cm})\end{array}$ & $\begin{array}{c}\text { Mean } \pm \text { SD } \\
(\mathrm{cm})\end{array}$ \\
\hline Kelompok I & $26,56 \pm 1,50$ & $22,89 \pm 1,69$ & $3,67 \pm 0,88$ \\
Kelompok II & $25,67 \pm 1,22$ & $22,56 \pm 1,13$ & $3,11 \pm 0,92$ \\
\hline
\end{tabular}

Berdasarkan Tabel 2. Diatas menunjukkan bahwa hasil nilai Chair Sit and
Reach Test pre and post melakukan terapi dan data kedua kelompok diambil sesudah melakukan terapi $3 x$ dalam 1 minggu selama 6 minggu. Ditunjukkan terdapat perubahan pada pengukuran Chair Sit and Reach Test.

\section{Uji Normalitas Dan Homogenitas}

Tabel 3

Hasil uji normalitas dan homogenitas

Berdasarkan Tabel 3 diatas, didapatkan nilai $p>0,05$ untuk pre dan post kedua Kelompok yang berarti sampel berdistribusi normal. Sedangkan pada uji homogenitas dengan menggunakan Levene's Test, dari nilai Chair Sit and Reach Test Kelompok I dan II sebelum intervensi diperoleh dimana nilai $p>0,05$, bahwa untuk Kelompok I dan II yaitu homogeny (sama). Tidak terdapat perbedaan signifikan pada tingkat fleksibilitas otot hamstring pada penderita osteoarthritis genu.

\section{Uji Efek Terapi Untuk Kelompok I dan II Sebelum Dan Sesudah Terapi}

Tabel 4

Uji hipotesis pada kelompok I \& II

\begin{tabular}{|c|c|c|c|c|}
\hline \multirow{2}{*}{$\begin{array}{l}\text { Kelompok } \\
\text { Perlakuan }\end{array}$} & $\begin{array}{l}\text { Intervensi } \\
\text { Mean } \pm \text { SD }\end{array}$ & & \multirow[t]{2}{*}{$t$} & \multirow[t]{2}{*}{$p$} \\
\hline & $\begin{array}{l}\text { Pre } \\
(\mathrm{cm})\end{array}$ & $\begin{array}{l}\text { Post } \\
(\mathrm{cm})\end{array}$ & & \\
\hline Kelompok I & $26,56 \pm 1,50$ & $22,89 \pm 1,69$ & 12,70 & 0,000 \\
\hline Kelompok II & $25,67 \pm 1,22$ & $22,56 \pm 1,13$ & 10,05 & 0,000 \\
\hline
\end{tabular}

Berdasarkan tabel di atas diperoleh hasil $p=0,000$ untuk flexibilitas otot hamstring sesudah terapi terhadap kedua kelompok, dimana $p>0,05$. Bahwa untuk Kelompok I dan II, terjadinya peningkatan flexibilitas otot hamstring sesudah terapi secara bermakna dan signifikan karena terapi yang diterapkan.

\section{Uji Beda Efek Perlakuan Untuk Kelompok I dan II Sebelum Dan Sesudah Terapi.}

Tabel 5

Hasil uji beda kedua kelompok

$\begin{array}{lll}\text { Intervensi } & T & p\end{array}$




\begin{tabular}{ccccc}
\hline $\begin{array}{c}\text { Kelompok } \\
\text { Perlakuan }\end{array}$ & $\begin{array}{c}\text { Pre } \\
(\mathrm{cm})\end{array}$ & $\begin{array}{c}\text { Post } \\
(\mathrm{cm})\end{array}$ & & \\
\hline Kelompok I & $26,56 \pm 1,50$ & $22,89 \pm 1,69$ & 1,37 & 0,190 \\
Kelompok II & $25,67 \pm 1,22$ & $22,56 \pm 1,13$ & 0,492 & 0,631 \\
\hline
\end{tabular}

Berdasarkan hasil Uji T-Independent dari data tersebut menunjukkan distribusi data normal baik pada kedua Kelompok. Hasilnya untuk membandingkan nilai rata-rata Chair Sit and Reach Test sesudah terapi Kelompok I dan II. Hasil dari T-Independent menunjukkan dimana nilai $p>0,05$. Di peroleh tidak ada perbedaan bermakna untuk kedua Kelompok dalam meningkatkan flexibilitas otot hamstring.

\section{PEMBAHASAN}

\section{Gambaran Umum Pasien}

Pasien dalam uji praktek yang telah memenuhi kriteria insklusi berjumlah 18 orang di RSUP Sanglah Denpasar Bali, yang di bagi jadi 2 kelompok ialah 9 orang untuk Kelompok I dan II dengan menggunakan tehnik acak sederhana.

Umur sampel yang telah di pilih untuk sampel penelitian pada kedua Kelompok ialah Klelompok I rentangan 60-80 tahun, rerata 66,22, dengan standar deviasi 4,02 dan Kelompok II rentangan 60-80 tahun, rerata 66,36 dengan standar deviasi 6,36. Hal ini ditujukan sampel penelitian mempunyai karakteristik usia yang tidak berbeda bermakna. Pengaruh umur terhadap fleksibilitas di mulai dari anak-anak yang terjadinya peningkatan kelenturannya tetapi beranjak dewasa terjadinya penurunan di karenakan pola aktivitas tak lagi aktif seperti ketika usia anak-anak, terutama beranjak lanjut usia bilamana terjadinya berbagai macam kasus penyakit khususnya degenerative. Secara umum pada jenis kelamin perempuan lebih lentur dibandingkan pria, di karenakan faktor hormonal dimana pria mempunyai hormone testoteron yang dapat mempengaruhi pemendekan dan pertumbuhan otot. Sedangkan wanita mempunyai hormone estrogen yang dapat mempengaruhi kelemahan sendi dan panjang otot $^{10}$. Faktor di atas menjadi salah satu yang bisa mempengaruhi pada kinerja seseorang, di karenakan perempuan dan pria mempunyai perbedaan dalam daya tahan tubuh. Secara umum perempuan lebih banyak terjadinya penurunan aktivitas normal di bandingkan laki-laki karena aktivitas perempuan sangat rumit seperti melakukan pekerjaan rumah. Aktifitas yang static akan mempengaruhi kinerja otot, serta menyebabkan terjadinya penurunan jumlah kolagen dan ukuran serat, sehingga melemahnya jaringan. Terdapat peningkatan proposional dalam dominasi elastin serat, serta terjadi peningkatan secara maksimal ${ }^{11}$.

Rentangan berat badan sampel penelitian pada Kelompok I berat badan 50-70 $\mathrm{kg}$, rerata $52,00 \mathrm{~kg}$ dengan standar deviasi 1,73 dan pada Kelompok II berat badan 50-70 $\mathrm{kg}$, rerata $54,89 \mathrm{~kg}$ dengan standar deviasi 3,62 . Sedangkan rentangan tinggi badan $150-$ $170 \mathrm{~cm}$, rerata 159,44 cm dengan standar deviasi 3,12 dan pada Kelompok II 150-170 $\mathrm{cm}$, rerata $160,22 \mathrm{~cm}$ dengan standar deviasi 4,46. Pada kelompok sampel penelitian mempunyai karakteristik berat badan dan tinggi badan yang tidak berbeda bermakna.

Seseorang yang berat badan yang besar atau gemuk memiliki gaya gesekan yang besar juga antar sendinya dan serta menyebabkan nyeri dalam kondisi osteoarthritis. Penurunan BB (berat badan) $1 / 2 \mathrm{~kg}$ dapat mengirit beban lutut $2 \mathrm{~kg}$ dan mengurangi berat badan $2 \mathrm{~kg}$ bisa meminimalisir resiko osteoarthritis genu 50 persen untuk wanita ${ }^{\mathbf{1 2 , 1 3}}$. Di nyatakan dengan makin kasar permukaan benda yang saling bergesekan maka tambah besar pula gaya gesekannya serta terjadinya penipisan pada tulang kartilago dan terdapat timbulnya tulang baru disekitar pinggir-pinggir tulang yang akan menyebabkan permukaan tulang jadi tidak halus sehingga antar tulang akan terjadinya gesekan yang hebat maka akan pembatasan dalam pergerakkan dan menyebabkan nyeri disekitar lutut. Besar gaya gesekan dapat di kontrol dengan nilai koefisien. ${ }^{\mathbf{1 4 , 1 5}}$ Memperhalus permukaan sendi 
dengan melakukan kontak, seperti contoh cairan sinovial pada sendi yang melumasi persendian tulang dapat memperkecil koefisien gesekan.

Pengaruh BB (berat badan) pada gaya gesek dibuktikan dengan hasil penelitian, bahwa makin tinggi berat badan dapat sangat besar juga gaya gesek yang diperoleh, sehingga setiap individu mempunyai perbedaan masing-masing untuk besar gaya gesekannya. Di peroleh hasil lainnya ialah bahwa pada penelitian ini terdapat hubungan gaya gesekan sendi disekitar lutut, sehingga dijelaskan makin tinggi gaya gesek terhadap persendian tulang, akan menimbulkan peluang besar dengan terjadinya osteoarthritis. Menjaga BB supaya proposional menjaga pola makan yang seimbang dan lebih sering olahraga serta untuk mengangkat beban berat lebih di perhatikan atau terlalu sering, agar bisa menghindari timbulnya osteoarthritis.

\section{Hipotesis I dan II : Efek terapi ultrasound} dengan latihan hold relax dan latihan passive stretching dalam peningkatan flexibilitas otot hanstring.

Hasil penelitian ini akan menjawab hipotesis yang terdapat pada bab sebelumnya dengan penjelasan sebagai berikut :

Untuk menguji hipotesis I dan II dilakukan paired sample t-test. Dari hasil tes tersebut sama-sama di peroleh dengan nilai $p=0,000$ artinya $p>0,05$ yang berarti pada masing-masing kelompok, terjadi peningkatan fleksibilitas otot hamstring sesudah terapi secara bermakna dan signifikan karena terapi yang diterapkan.

Penelitian oleh Leong, dkk ${ }^{\mathbf{1 6}}$; Dengan membuktikan dengan diberikannya Low Intensity Pulsed Ultrasonic (LIPUS) dalam kasus nyeri lutut dapat mebantu untuk memperbarui kemajuan kasus dan mengurangi nyeri yang di rasakan oleh seseorang. Menurut Hardjono, $\mathrm{dkk}^{\mathbf{1 7}}$; Di mana pada ultrasound sebagai rileksasi otot serta mempercepat proses penyembuhan jaringan. Ultrasound bisa mempengaruhi peningkatan zat anti bodi dan pembuluh darah sehingga terjadinya peningkatan suplai bahan makanan, transport protein yang bisa memudahkan dalam mempengaruhi pemulihan serta regenerasi jaringan yang rusak. Ultrasound juga memiliki efek sedative yaitu dapat memberikan peningkatan pada fleksibilitas otot sehingga masalah yang dikarenakan keterbatasan gerak bisa segera berkurang.

Menurut Kisner, $\mathrm{dkk}^{6}$ : Bahwa hold relax memiliki tujuan untuk mengurangi muscle spasme telah terjadi pemendekkan akan terjadinya peningkatan pada kelenturan otot, menurunkan muscle spasme, meningkatkan kekuatan otot, dan bisa menurunkan resiko traumatic untuk otot sehingga diberikannya tehnik inhibisi agar memperoleh panjang pada otot. spasme otot terjadi di dalam serat otot seandainya dalam jangka waktu cukup lama maka akan terbentuknya nodule di karenakan ishkemik dalam pembuluh darah bagian bawah, sehingga akan membentuk metabolism di sekitar muscle tersebut tidaklah mudah maka muncullah rasa nyeri. Tehnik fleksibilitas hold relax, latihan ini akan mengembalikan gerakan semula serta terjadinya penambahan panjang otot maka metabolism di sekitar ototnya akan mudah dalam mengurangi rasa nyeri.

Penelitian ini sesuai yang dilakukan oleh Amin, $\mathrm{dkk}^{\mathbf{1 8}}$ menyatakan ; Bahwa pada metode hold relax sangat berpengaruh dalam peningkatan fleksibilitas otot hamstring dikarenakan rangsangan passive stretching and autogenich inhibition. Respon autogenic telah teraktivasi karena beberapa dari otot sampel terjadinya kontraksi maksimal secara secara isometric dengan waktu pelaksanaan 10s. Latihan ini secara maksimal akan merangsang motor unit dengan mengaktivasi golgi tendon organ pada jaringan otot.

Ahmed, $\mathrm{dkk}^{\mathbf{1 9}}$ dalam penelitiannya menyatakan : Latihan ini terjadinya kontraksi maksimal secara secara isometric akan memberikan rangsangan pada golgi tendon organ untuk memberikan respon penekanan, dikarenakan golgi tendon organ memberikan 
sinyal protektif pada respon yang kebanyakan untuk jaringan maupun otot. Ketika memberikan respon pada SSP melewati ST (Saraf Tepi) mendapatkan hasil rileksasi untuk otot dan menginhibisinya juga.

Menurut Juliantine, $\mathrm{dkk}^{\mathbf{2 0}} ;$ Passive stretching dilakukan sampai sampel terasa sakit. Setelah sampel terasa sakit, diberikan regangan lebih pada saat itulah refleks muscle spindle teraktivasi ketika dalam posisi terulur maka muscle spindle terbiasa dengan panjang otot yang baru. Muscle spindle memicu stretch refleks dan secara bertahap terlatih untuk memberikan penguluran yang lebih lagi. Pemanjangan otot ini yang meningkatkan kelenturan otot hamstring yang melemah.

Stretching adalah salah satu jenis terapi bertujuan meningkatkan panjang otot dimana telah terjadinya penurunan elastisitas atau pemendekkan otot dan fleksibilitas otot yang baik karena akibat patologis (trauma, infeksi, dsb) maupun yang bersifat fisiologis, yang normal yaitu terjadinya pemendekkan, perlengketan, pemendekkan otot telah terjadi dalam perubahan bentuk jaringan parut, kulit dan jaringan konektif serta mobilitas jaringan lunak di sekitar sendi ${ }^{21}$.

3. Hipotesis III : Perbedaan efektifitas terapi ultrasound dengan latihan hold relax dan latihan passive stretching pada peningkatan flexibilitas otot hanstring.

Hasil dari uji T-Independent di dapatkan nilai $p=0,631$, dimana $p>0,05$. Telah disimpulkan, tidak ada perbedaan bermakna pemberian intervensi terapi ultrasound dengan latihan hold relax dan latihan passive stretching pada peningkatan fleksibilitas otot hamstring.

Sebagaimana sesuai dengan penelitian Ah Cheng, dkk ${ }^{22}$ yang menyatakan ; bahwa efek fisiologis ultrasonic di antaranya memberikan peningkatan metabolisme, peningkatan keringat, peningkatan kapiler, tekanan dan permeabilitas, vasodilatasi lokal dengan hiperemi, rileksasi otot melewati muscle spindle dan golgi tendon organs linear, peningkatan tekanan oksigen, peningkatan jaringan kemungkinan di perpanjang dengan sedasi sensorik saraf. Efek fisiologis dari aplikasi panas tergantung pada peningkatan suhu jaringan target ke tingkat terapi, suhu mencapai 8-10 menit menanggapi stimulus panas, tubuh memproduksi respon fisiologis yang diterapi

Tehnik hold relax di mulai dengan kontraksi isometric otot antagonis telah merangsang stimulus golgi tendon organ maka akan membangunkan mekanisme inhibitory, akibatnya menghambat kekuatan impuls motoric yang menuju ke arah otot antagonis. Pengurangan impuls motoric terhadap otot antagonis telah menimbulkan lemahnya kontraksi otot antagonis yang dapat menjadi penurunan dalam kinerja otot agonis, sehingga membuat gerak otot agonis menjadi luas \& mudah. Selain itu, kontraksi otot antagonis terjadinya penurunan dimana spasme otot menjadi berkurang serta rangsangan terhadap nociseptor (organ penerima rangsang nyeri) telah berkurang pula, akibatnya tidak membangkitkan rasa nyeri.

Lain hal dengan passive stretching yang menghasilkan peningkatan panjang otot antagonis secara langsung lalu meniimbulkan peningkatan spasme otot antagonis akhirnya terjadinya hambatan pada gerakan ke arah agonis. Passive stretching akan rileks atau kendor jika diberikan penguluran pada otot antagonis. Rileks bisa berubah pada otot antagonis dikarenakan muscle spindle organs. Jika tidak ada perubahan pada panjang otot, maka muscle spindle organs tidak akan dapat stimulus. Tapi, kalau terdapat kontraksi sehingga menyebabkan penambahan panjang otot maka muscle spindle organs mendapatkan rangsangan. Lalu untuk latihan ini dapat meningkatkan tonusnya serta menghambat panjang otot.

Golgi tendon organ merupakan reseptor berada di antara serabut otot dan tendon otot berguna untuk membangunkan susunan inhibitory (hambatan) kekuatan impuls motoric melewati ke otot, sehingga mengurangi kekuatan kontraksi otot. Golgi 
tendon organ di rangsang oleh spasme yang di peroleh dengan serabut otot. Jika golgi tendon organ di rangsang maka akan melepaskan impuls yang di teruskan ke medulla spinalis, hal ini akan membangunkan susunan hambatan serta menghambat kekuatan impulse motoric melewati otot.

Teori diatas telah menjelaskan tentang hasil dari kegunaan pada peningkatan flexibilitas otot hamstring , ke dua latihan ini sama - sama mmenghambat golgi tendon organ dan menimbulkan reaksi reverse innervation, reaksi ini berdampak dalam memberikan pemanjangan otot yang baru. Shankar dan Yogita ${ }^{23}$; Dengan hasil bahwa untuk meningkatkan flexibilitas otot hamstring, hold relax lebih baik daripada terapi latihan Passive stretching. Pengaruh hold relax yang lebih baik dibanding Passive stretching pada peningkatan fleksibilitas otot hamstring tersebut sesuai pula dengan mekanisme yang terjadi pada muscle spindle organs dan golgi tendon organs. Muscle spindle organs sangat sensitif terhadap perubahan panjang (length) otot, jika pada saat otot diulur responnya berupa mempertahankan panjang (tonic response) untuk memelihara posisi ( posture ) / mengubah panjang (phasic response) saat bergerak.

Berdasarkan penelitian Amin, $\mathrm{dkk}^{\mathbf{1 5}}$; Tehnik hold relax lebih baik dalam peningkatan flexibilitas otot hamstring karena respon autogenic inhibition dan di campur passive stretching untuk latihan ini. Respon autogenic inhibition yang teraktivasi karena otot hamstring sebagai sasaran untuk dilakukannya kontracsi maximal.

Peningkatan fleksibilitas otot hamstring diakibatkan oleh faktor lain seperti usia, jenis kelamin dan aktivitas. Peneliti tidak dapat mengendalikan aktivitas di luar latihan sehingga dapat mempengaruhi hasil latihan. Menurut yang diungkapkan oleh Wiguna, 2013 ; Secara umum perempuan lebih lentur ototnya daripada pria. Pria memiliki hormone testosterone akan menimbulkan pemendekan dan pertumbuhan otot sedangkan perempuan memiliki hormone estrogene yang bisa menimbulkan kelemahan sendi dan meningkatkan panjang otot.

\section{KETERBATASAN PENELITIAN}

Keterbatasan pada penelitian ini yang bisa menimbulkan hasil yang berbeda dari penilaiannya, yaitu :

$>$ Peneliti tidak bisa mengontrol aktivitas sampel di luar terapi yang dapat mempengaruhi kondisi fisik dan psikis sampel.

\section{SIMPULAN}

Berdasarkan hasil penelitian dan pembahasan tentang terapi ultrasonic dengan latihan hold relax dan terapi ultrasonic dengan passive stretching pada peningkatan fleksibilitas otot Hamstring di RSUP Sanglah Denpasar Bali, didapatkan hasil :

1. Terapi ultrasound dengan latihan hold relax dapat meningkatan fleksibilitas otot Hamstring di RSUP Sanglah Denpasar Bali.

2. Terapi ultrasound dengan passive stretching dapat meningkatan fleksibilitas otot Hamstring di RSUP Sanglah Denpasar Bali.

3. Terapi ultrasound dengan latihan hold relax dan terapi ultrasound dengan passive stretching sama-sama meningkatan fleksibilitas otot Hamstring di RSUP Sanglah Denpasar Bali.

\section{SARAN}

1. Untuk penelitian berikutnya diharapkan faktor aktivitas sampel di luar penelitian dapat dikontrol dengan baik sehingga diperoleh hasil yang maksimal.

2. Selain itu penulis berharap untuk penelitian berikutnya, agar menambahkan kriteria insklusi batas lingkup gerak sendi, ataupun range penilaian fungsional pada pasien osteoarthritis genu agar sampel lebih homogen. 


\section{DAFTAR PUSTAKA}

1. Soeroso, Joewono,. 2006; Osteoartritis. Su doyo A.W, Setiyohadi B, Alwi I, Simadibr ata $\mathrm{M}$, Setiati S, Editor. Buku ajar ilmu p enyakit dalam. 4th ; edition.

2. Onigbinde, A.T. Akindoyi, O. Faremi, F. A. Akonji, A., Shuaib, O. \& Lanre, O. O. (2014). An Assessment of Hamstring Fle xibility of Subjects with Knee Osteoarthriti $\mathrm{s}$ and Their Age Matched Control. Clinical Medicine Research. No ; 2, Vol ; 6, Hal ; (121-125).

3. Bushman, B And American College of Sp ort Medicine; 2017, Complete Guide to Fit ness And Health.

4. Utomo dan Pujiastuti., 2002; Fisioterapi $P$ ada Lansia. Jakarta ; EGC.

5. Stephens B, Julie G, Donna, F, And C. D exter, K, 2005 ; The Impact of Stretching on Sports Injury Risk; A Systematic Revie $\mathrm{w}$ of the Literature of the American Colle ge of Sports Medicine. 04 (0195-

9131), (3603-0371).

6. Kisner C, \& Colby L, A (2007) ; Therape utic Excercise Foundation and Technique.

5 thed: F, A, Davis company, Philadelpia ; 149-222, 314-316, 744-751

7. Arovah N, I, (2010) ; Dasardasar Fisioterapi pada Cedera Olahraga, D.I.Yogyakarta.

8. Eveleigh J, (2013) ; PNF Stretching. http:/ lwww.stretching-exercisesguide.com/pnfstretching.html : Diakses pad a tanggal, 24/01/2014

9. Sugijanto, Nur B. Timbul, \& Johanes. 20 09. Manual Terapi Regio Knee Joint; Sur akarta.

10. Wiguna A. Silakarma D \& Sundari R. (2 015). Intervensi Contract Relax Stretching dengan Passive Stretching terhadap Fleks ibilitas Otot Hamstring pada Atlet Taekw ondo dari Underdog Taekwondo Club. $M$ ajalah Fisioterapi Indonesia ; Vol : 2 No $: 1$.
11. Kisner C. \& Colby LA. (2007). Therapeu tic Excercise Foundation and Technique. 5 thed, F. A. Davis company. Philadelpia ; 149-222, 314-316, 744-751.

12. Soenarwo H. B. M. Osteoarthritis. Jakarta ; Halimun Medical Centre \& AlMawardi Prima (2011) : p. (7-15).

13. Messier SP, Gutekunst DJ, Davis C, and DeVita P : Weight loss reduces kneejoint loads in overweight and obese older adu lts with knee osteoarthritis. Arthritis \& Rh eumatism. (2005) ; 52 (7) ; (2026-2032).

14. Helmtrud I. Roach, Simon T. Bone \& Os teoarthritis, London ; Springer, (2007) : p , (1-3).

15. Knudson, Duane. ; Fundamentals of Biom echanics. California State University : Spr inger (2007) ; p, (146).

16. Leong DJ. Tang J. Hirsh DM. Zhang H, $\mathrm{Xu}$ L, et al. Therapeutic Ultrasound: Oste oarthritis Symptom-

Modification and Potential for Disease Mo dification. J Surgery, (2013) : 1 (2) ; 5.

17. Hardjono J, (2012) ; Pengaruh Penambaha $\mathrm{n}$ Contract Relax Stretching Interversal Int erferensial Current dan Ultrasound Terha dap Pengurangan Nyeri Pada Sindroma M iofascial Musculus Supraspinatus. Jakarta Barat, Universitas Esa Unggul.

18. Amin A, A. purnawati.S, \& Lesmana S. I . (2015). Metode Active Isolated Stretchin $g$ dan metode hold relax stretching sama efektif dalam meningkatkan fleksibilitas ot ot hamstring pada mahasiswa akademi fis ioterapi widya husada semarang yang me ngalami hamstring muscle tightness (HMT s). Vol ; 3, No ; 2 (11-

22). Agustus (2015). Tesis Bali ; Universi tas Udayana.

19. Ahmed H. Iqbal A. Anwer S. \& Alghadir , A. (2015); Effect of modified hold relax stretching and static stretching on hamstri ng muscle flexilibity. J. Phys, T (536) her, Sci. Vol : 27, No : 2 (2015). 
20. Juliantine T. (2012) ; Studi Perbandingan Berbagai Macam Metode Latihan Peregan gan Dalam Meningkatkan Kelentukan. Jur nal Pendidikan Olahraga. http://file.upi.ed u/Direktori/FPOK/JUR.PEND.OLAHRAG A/1968070799 2032 TITE_JULIANTINE/ 4.JURNAL_METODEPEREGANGANx.pd f. Diakses pada Tgl 5/11/2016.

21. Irfan M, \& Natalia, (2008) ; Beda Pengar uh Auto Stretching dengan Contract Rela $\mathrm{X}$ and Stretching Terhadap Penambahan $\mathrm{P}$ anjang Otot Hamstring. Jurnal Fisioterapi Indonusa, No : 8, Vol : 1, Hal : 65 8.

22. Ah Cheng Goh ; (2014). An evidence bas ed model for determining treatment dosag es in therapeutic ultrasound using thermo metry: an invitro investigation using postmortem pig tissues. PhD Thesis, Curtin U niversity ; Perth.

23. Shankar G. \& Yogita, (2010) ; Efectivene ss of passive stretching versus hold relax technique in fleksibility of hamstring mus cle : (OJHAS) Gujarat, India. 